\title{
10. Tangible heritage of the Macassan-Aboriginal encounter in contemporary South Sulawesi
}

\author{
Marshall Clark
}

\section{Introduction}

There are several under-explored areas in the scholarship on the so-called 'Macassans', the trepang fishers of diverse ethnicity originating from the Sulawesi port of Makassar who voyaged to the coastline of northern Australia to fish for trepang, also known as sea cucumber, from at least 1720 to the $1906 / 7$ season. The most noticeable gap in the field is in respect to China, the final destination of the processed trepang in the Macassan era. ${ }^{1}$ The other relatively under-explored area is Makassar itself, the major disembarkation point for the Macassan trepang fishing fleets. This chapter will partly redress this scholarly lacuna by highlighting Makassar's Macassan heritage, with an emphasis on tangible heritage. The body of this chapter will discuss what could be understood as Macassan tangible cultural heritage: authentic monuments and historical sites with distinctive connections to the Bugis and Makassarese fishers and entrepreneurs of centuries past. But it will soon become evident that in the contemporary era there is very little in the way of tangible Macassan heritage, either in Makassar itself or in South Sulawesi in general.

This sorry state of affairs might not have needed to be the case. As a point of comparison, the penultimate section of this chapter will discuss the seafaring and fisheries galleries in the Terengganu State Museum in the port city of Kuala Terengganu on the eastern coastline of peninsular Malaysia. Such a comparison is apt because in many respects Terengganu and Makassar can be considered as cultural counterparts, most obviously in the sense that they have long been ports of significance in archipelagic Southeast Asia. This comparative discussion is not meant to be exhaustive, but rather an illustration of how a tangible Macassan or seafaring cultural heritage might have been - or still yet could be-embodied or interpreted.

Of course, it should be noted from the outset that using a Malaysian heritage case study as a point of comparison with Makassar has its flaws. As Karim Raslan

1 A notable exception is Sutherland (2000). 
observed in the mid 1990s, Malaysia is a middle-class nation with middle-class preoccupations (Raslan 1996, p. 128). Today this is even more so the case. One of these preoccupations is the preservation and promotion of history and heritage. In Malaysia, the promotion of museums, traditional craft fairs and cultural theme parks, with the associated 'museumising' of the material culture of both the modern and the past, is closely related to government initiatives to instil national pride among Malaysian citizens (Hoffstaedter 2008). The Malaysian Government has a proclaimed aim of Malaysia becoming a fully industrialised country by 2020, and modern elements of this project, such as Kuala Lumpur's Petronas Twin Towers, the tallest 'twin towers' in the world, are given equal weighting to 'traditional' elements of the nation's narrative, such as the sultan's palace with its wood-crafted dwellings and the many material cultural artefacts found in museums and theme parks (Hoffstaedter 2008). The post-colonial state's reification, which Nor (2011, p. 53) calls 'heritagization', of traditional Malay court and folk dances, is another expression of this pattern. Kuala Lumpur's Handcraft Museum, with its 'colony' of artists and artisans employed for the purposes of daily performances of batik-making, jewellery-making, dancing, and so on, is a similar expression of this museumising impulse. ${ }^{2}$

In contrast with Malaysia, Indonesia is a vastly different kettle of fish. ${ }^{3}$ In terms of economic progress and democratic consolidation, developing Indonesia is still very much a work in progress. In terms of print literacy, despite rising educational levels and a sharp decline in the level of illiteracy, Indonesia's oral cultural and literary traditions still predominate (see Derks 1996, 2002). This means that libraries and other cultural institutions such as museums are in an important sense anachronistic, marginal phenomena harking back to the colonial era. Museums are also poorly patronised, as besides the colonial overtones described above, state museums have long been seen as sites of New Order indoctrination. Fortunately, it can be argued that in Makassar, as in Indonesia in general, 'living history', as opposed to the anachronism of 'museumified' history, is far more relevant. This chapter will argue, therefore, that any serious

2 Given its undeniable lack of authenticity, not to mention its blatant exploitation of rural artisans, India's national handicrafts museum in New Delhi has been harshly criticised (see Greenough 1993; Bharucha 2000). Similar criticisms can be levelled at the Kuala Lumpur Handcraft Museum.

3 In fairness, it should be noted that, despite the obvious economic differences, Indonesia has not been completely left behind by its wealthier neighbours. For instance, there is a modest amount of museumising in Indonesia, such as the well-established Taman Mini Indah Indonesia theme park in Jakarta and the Sultan of Yogyakarta's Palace in Central Java, which has a number of ceremonial and historical artefacts. Moreover, there appears to be modest growth in the establishment of new museums and cultural heritage tours and trails, particularly in regional cities and towns such as Magelang, Jepara, Banten and Demak. With rising incomes, the regions appear to be seeking to claim and highlight their specific and unique heritage and culture. But on the whole these efforts are still poorly funded, ad hoc in nature and poorly patronised. The governmentfunded Makassar City Museum, for example, is unkempt and dusty, with depressingly inadequate lighting and labelling. The museum is free of charge and is manned by student volunteers with little understanding of the historical significance of any of the museum artefacts, which are seldom rotated or enhanced by new acquisitions. 
examination of the Macassan history and heritage of contemporary Indonesia must move beyond a negative comparison with a Malaysian cognate form. Instead, it should be premised on the understanding that the contemporary Macassan or maritime culture of South Sulawesi is an ongoing cultural process, an intangible 'living history', rather than an objective cultural product. The final section of this chapter will delineate this argument in more detail.

\section{Contemporary Makassar and the question of World Heritage listing}

If perchance a historian were to put on a stout pair of boots and search for evidence of tangible Macassan heritage in present-day Sulawesi, the phrase 'blink and you'll miss it' is apt. But this should not mean that there is no Macassan heritage in Indonesia-far from it. This is especially the case if the Macassan heritage of Sulawesi is defined not simply in terms of a selection of tangible cultural products but rather as an ongoing cultural process with associated intangible values. To do this, however, Macassan heritage needs to be understood as an element of a continuous and dynamic process by which a variety of identities is formed. Part of this process is to understand the ongoing 'boom-town' nature of contemporary Makassar itself.

Makassar is now one of the largest cities in Indonesia and, after Jakarta and Surabaya, the third-largest port city. The city, which was known in the New Order period as Ujung Pandang, is the capital city of the province of South Sulawesi. Makassar is also southern Sulawesi's primary port and has many domestic and international shipping connections, which means that it is the major maritime trading centre of the eastern part of the Indonesian archipelago. Makassar has a modest international airport, with direct and regular flights to and from Singapore, Jakarta, Denpasar, and many other domestic destinations, including all the major centres in Sulawesi. Makassar has been described, somewhat romantically, in the following way:

Bugis schooners, the ancient walls of the city and the minarets and domes of mosques impart a medieval look to South Sulawesi's bustling port and capital, Ujung Pandang. Indeed, the city still exhibits many vestiges of the 16th century when it was known the world over as Macassar, maritime center of the Dutch East Indies. (Behr 1990, p. 204)

Two decades later, much of this description holds true. In Makassar's Paotere Harbour, among many other types of vessels, there certainly are the odd pinisi (Bugis schooner) or two, distinguished by their spectacular masts and spinnakers. The minarets and domes of Makassar's mosques are still in abundance. 
The imposing walls of Fort Rotterdam are a stark reminder of Makassar's Indies past. During the early mornings and evenings, when the adzan, or Muslim call for prayers, over numerous loudspeaker systems seems particularly pronounced, Makassar's Muslim heritage is obvious. These days, however, the Makassar skyline is dominated by a string of five-star luxury hotels along the Losari beachfront thoroughfare, not to mention the many large container cranes at Makassar's main wharf. As the region's major trading hub, Makassar is the selfproclaimed gateway to the many provinces and islands of eastern Indonesia and to the idyllic heritage tourism area of Tanah Toraja in the highlands of South Sulawesi. Much has been written about the rich Torajan cultural heritage, with an emphasis on the role of heritage tourism and its impact on traditional Torajan society and culture (see, for example, Adams 2006; Waterson 2011). There have also been ongoing calls for the Toraja region to be proposed as a site for the UNESCO World Heritage List (Adams 2010).

Despite the push for Tanah Toraja to be listed by UNESCO as a World Heritage site, there has so far been little interest in listing tangible or intangible evidence of South Sulawesi's major role in the Macassan trepang industry, which is a significant feature of the history of the region. As Macknight (1976) and many others have observed, the regular arrival of the Macassan fleets along the coastline of northern Australia resulted in frequent social, cultural and economic interactions between the trepangers and the peoples of the Australian coastline, which included the movement of Australian Aboriginal people to live, work and die in Makassar. The Macassan heritage is therefore imbued with cultural and historical significance for the Indigenous people of northern Australia and for the people of South Sulawesi, which, most neutral observers agree, needs to be rediscovered, preserved and conserved. As Indonesia's vibrant democratic consolidation begins to attract more international investment and tourists, and allows for the growth of a truly globalised middle class, it may now be timely for Macassan heritage sites to be nominated for UNESCO listing as world heritage, perhaps in a joint proposal by Australia and Indonesia. More precisely, the Makassar-Marege' maritime trade route might be appropriate for nomination in the category of cultural routes, introduced by UNESCO's World Heritage Committee in the mid 1990s. There is also the possibility of documenting and assessing Australian components of the Macassan trepangers' heritage for inclusion on Australia's National Heritage List in recognition of their relevance in Australian history. At present, although none of the Macassan sites along the northern coastline has been inscribed on Australia's National Heritage List, they are protected as archaeological sites under the Northern Territory's Heritage Act 2012. 


\section{The case of Unusu Daeng Remba's house in Jalan Maipa}

The best-known Macassan heritage site, a house (see Figure 10.1), is in fact one that would fall short of UNESCO's requirements for World Heritage listing. The house is described by Macknight (1976, Plate 18) as 'the building said to have been Unusu Daeng Remba's house in Kampong Basi, Macassar'. Unusu Daeng Remba was captain of the Lakarinlong on its voyages to Arnhem Land between 1882-83 and 1889-90 and of the Kampong Basi in 1897-98, and he also sailed on several other boats, including the Mannongkoki. One of the most prominent captains as the trepang industry declined, he was known to have hosted Aboriginal people in his house in Makassar (Macknight 1976, p. 86). According to Ibu Saribinong Nganne (b. 1904), the daughter of another wellknown captain in the last years of the Macassan trepang industry, Using Daeng Rangka, at least two of the Aborigines were men who lived and worked in Remba's house and died there in the 1930s (Stephenson 2007, p. 31). Cooke (1987, p. 45) gives their names as Lahurru and Lakkoy, while Stephenson (2007, p. 31) names them Lahurruk and Lido. They were 'responsible for guarding the empang or fishponds at the back of the house, cleaning the mushollah [small Muslim prayer house]... and pump[ing] water up bamboo ducts to the house and mushollah' (Ganter 2006, p. 36). The Kampung Basi locale is around Jalan Maipa, a street that is now in central Makassar, walking distance from Makassar's palmfringed Losari Beach and several of Makassar's best-known luxury hotels. The main roof beams, posts and structural foundations of the house are said to have been constructed of ironwood brought back from Arnhem Land more than 100 years ago.

At this point it should be noted that Unusu Daeng Remba's house no longer exists. The house, which in its final form consisted of an impressive two-storey house and a row of boarding rooms and classrooms, set in a courtyard extending $50 \mathrm{~m}$ to the south, was demolished on 3 November 2011. This fact alone will ensure that it will never meet UNESCO's protection and management criteria. It was demolished so that the nearby upmarket Kenari Towers Hotel could construct a new wing. A sign in the front yard of the house, prominent on the day of the demolition and in the following weeks, read: 'Mohon Doa Restu: Lokasi Ini Akan Dibangun Kenari Tower Hotel Unit 2 [Please Offer Your Prayers of Blessing: This Location will be used to Build Unit 2 of the Kenari Tower Hotel].' The house was reportedly sold for Rp10 billion (US\$1 million), which by Indonesian standards is a fortune. There is little doubt that the neighbourhood around Jalan Maipa, which runs from the picture-postcard beach into an area of schools and luxury hotels, holds some of Makassar's most sought-after real estate. 
The previous owner of the property, K. H. Darwis Zakaria, was well aware of the heritage value of the house's timber. Before its demolition, in conversation with us, the visibly upset Darwis, who grew up in the house, claimed that it would be carefully collected and used in the construction of a new house on the rural outskirts of Makassar. Nevertheless, much of this historically precious timber was destroyed in the demolition and large chunks of it lay strewn amongst the ruins (see Figure 10.2). When we asked a neighbour why the leftover timber was not being collected-or indeed stolen, considering the very high cost of ironwood - the response was prescient: 'No-one would be brave enough to steal that wood, as it is sacred [keramat].' Carbon testing would probably confirm that the wood was well more than 100 years old and, therefore, would be considered, as the neighbours suggested, far too lapuk (dilapidated) for further use.

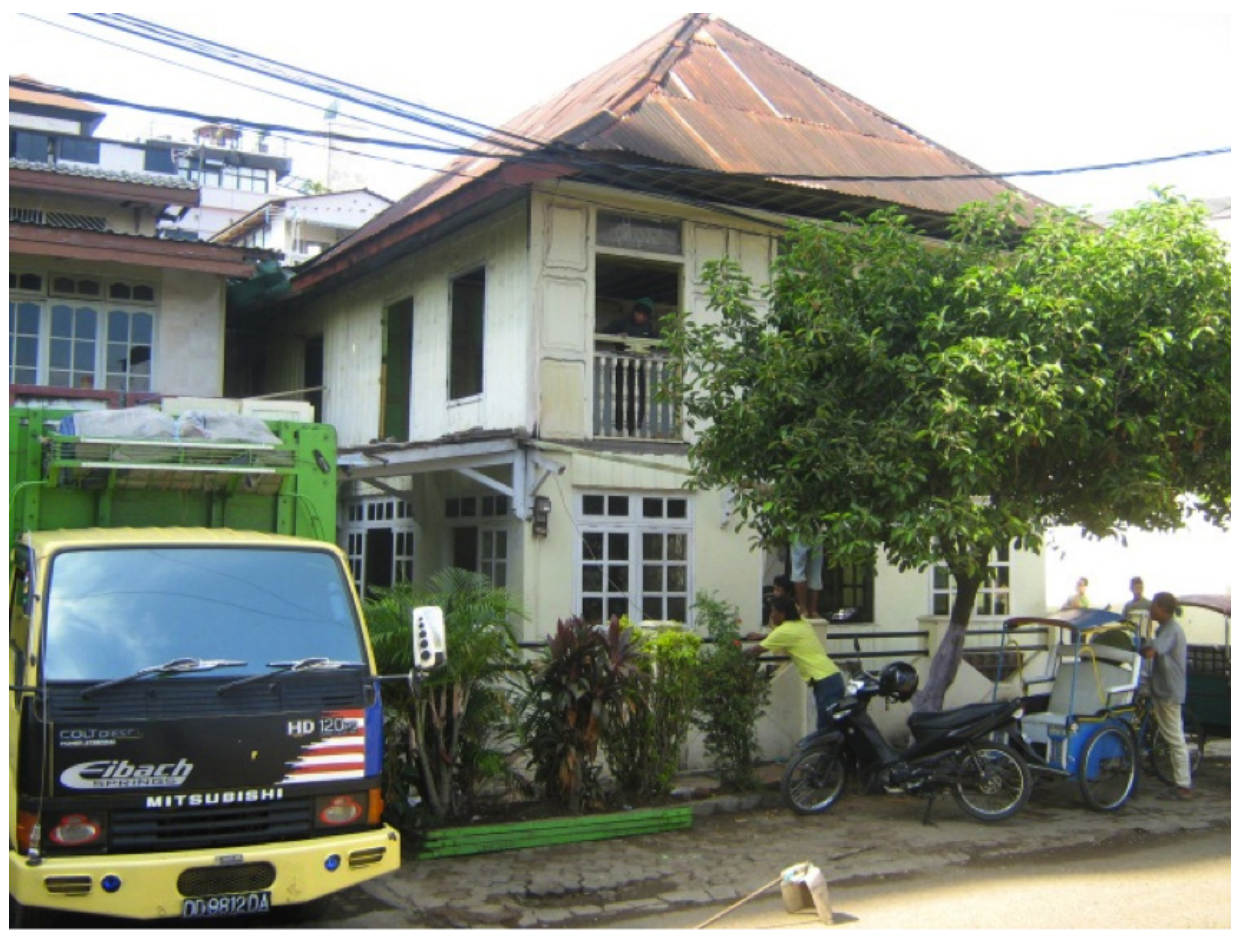

Figure 10.1 Unusu Daeng Remba's house in Jalan Maipa, Makassar, shortly before its demolition on 3 November 2011

Source: Marshall Clark 


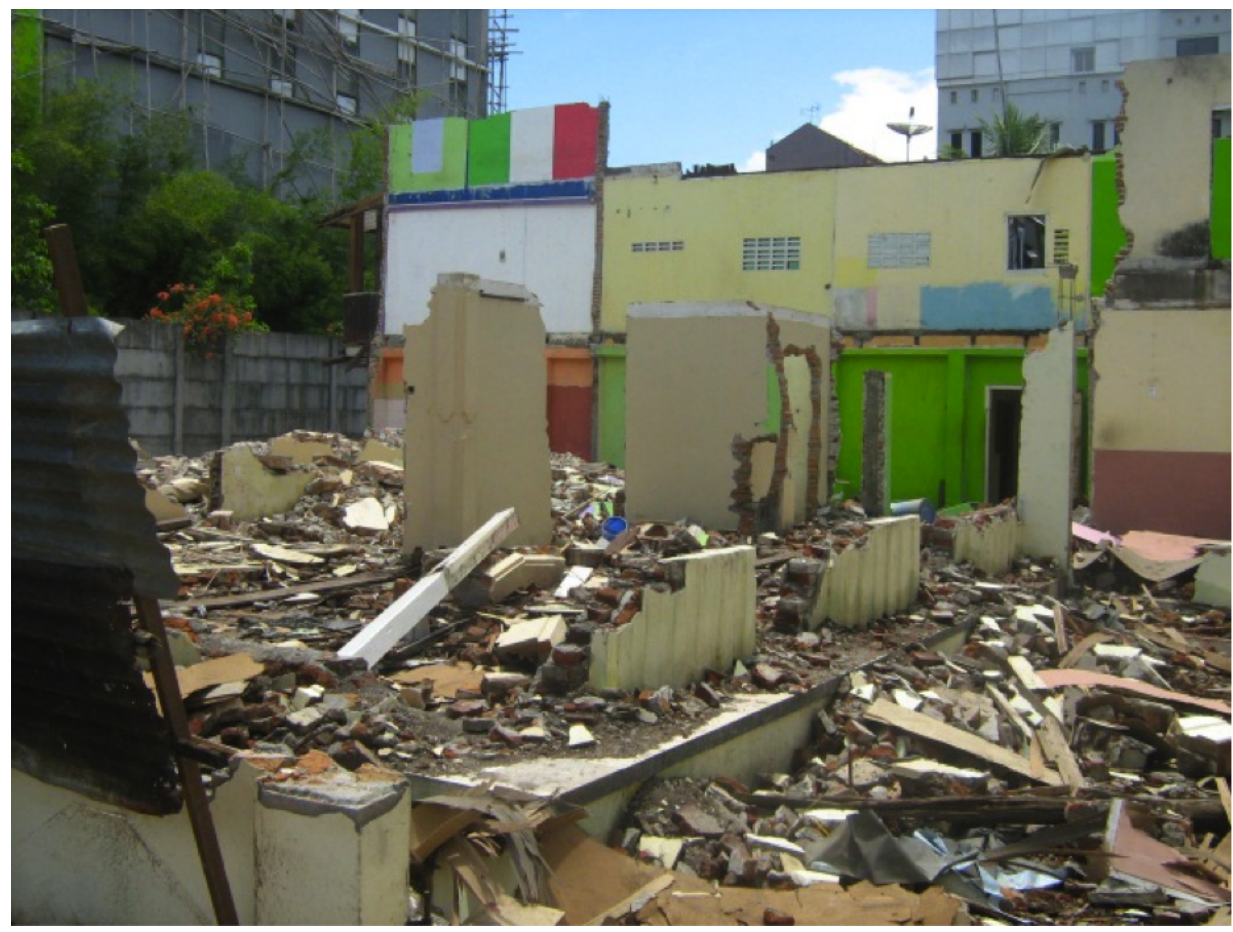

Figure 10.2 The remains of the Daeng Remba house, mid November 2011

Source: Marshall Clark

It was widely understood in the Jalan Maipa neighbourhood that the timber used in constructing Unusu Daeng Remba's house was transported from Arnhem Land in a boat captained by Daeng Remba more than 100 years ago. Some believed, perhaps mistakenly, that the house was built by a team of Aboriginal people. As noted earlier, Aboriginal Australians were known to have lived in the house, perhaps as slaves, from time to time. It is possible that an Aboriginal woman may also have lived at the Jalan Maipu house. Aboriginal people in Arnhem Land knew of an Aboriginal woman, Garngarr, who lived out her life in Makassar. Garngarr was taken as a teenage girl from Arnhem Bay, northeast Arnhem Land, to live in Makassar, where she married a Macassan man and had a number of children. At the age of ninety-nine, Garngarr was reunited in 1986 with a number of her family from northern Australia, including Yolngu elder Laklak Burarrwanga, who may be her great-great-granddaughter. 
Although the Garngarr story is shrouded in uncertainty, it is fascinating. According to Mattjuwi's account in Ganter (2006, p. 36), an Aboriginal woman from Elcho Island, not far from Arnhem Bay, named Garnggar, was abducted by someone known as Captain Maliwa. Cooke (1987, p. 45) suggests that this person may be Daeng Mallewa, a trepanger from the Spermonde island of Barrang Lompo. Ganter observes that Garnggar had a daughter, Gunano, who was born in Makassar. There are differing versions of Gunano's story, however, with varying accounts of how long she may have lived in Makassar, if at all. For instance, Macknight (1976, p. 87) reports that Using Daeng Rangka is said to have fathered about 10 children by three mothers in eastern Arnhem Land and one of his daughters there, Kunanu, later visited Makassar, but it is unlikely that she spent the rest of her life there. According to Mangngellai Daeng Maro, the son of Unusu Daeng Remba, 'a woman named "Kunano" went to Makassar and was later returned home before the end of the trepang industry with all the other Aborigines who were in Makassar at the time' (Cooke 1987, p. 43). Putting aside the question of how long Gunano/Kunano lived in Makassar, we can discount the notion that Gunano/Kunano is the same person as Garngarr/ Garnggar, as their names have not been linked by any sources. It remains difficult to determine precisely how Laklak is related to Garngarr/Garnggar and it is likely to remain difficult to do so. As noted by Cooke (1987, p. 39), 'most Aboriginal kinship terms simply do not have an English equivalent, and must be expressed in a roundabout way and with plenty of explanation'. Laklak's account of the reunion in Makassar in 1986 reads: 'When we got there she jumped from the chair and walked towards us saying this is the family from Arnhem Land. She was still thinking of when she left many years before. So we grieved. She was crying for me and we were crying for her' (Lloyd et al. 2010, p. 710).

After the initial reunion, stories were shared:

So we talked about what happened to her. She told stories. She was really old-about 99-but she was very strong. She told the story for the great grandsons. So we stayed there, made her company. Her husband had now died. We stayed for one night with her, me and my cousin Djalinda. The next day we went back and she called us up so that we should go to the museum where her nephew worked. His name was Hussein and we went to see. When she was young she was beautiful. We saw all the things she wore and her husband. We could see the sword. He was a prince, her husband. We see clothes. Everything was kept in the museum. (Burarrwanga 2012)

Garngarr has now passed away and, according to residents of Jalan Maipa, is purportedly buried with her husband somewhere in West Sumatra. Unusu Daeng Remba's great-great-grandchildren and other Jalan Maipa residents 
vividly recall a large group of Aborigines (presumably Laklak's group of six) touring the house several decades ago (in 1986, to be precise). Laklak has also recounted a few other Makassar-related stories, most notably that Garngarr worked at a church where she used to sweep and mop the wooden floor, which was apparently made of ironwood from northeast Arnhem Land. There is a Catholic school in the Kampung Basi locale, so perhaps this is an avenue for future investigation.

One further point about the Jalan Maipa house is that neighbours were certain that it was haunted. Haunted houses are not a phenomenon unique to Makassar, of course, as belief in ghosts and other supernatural activity is widespread and deeply rooted throughout maritime Southeast Asia. The stories of ghosts inhabiting the Jalan Maipa house may explain the general reluctance to tamper with the abandoned timber. One middle-aged man told us of how he had slept overnight in the house a few times when he was a boy. He distinctly remembers being disturbed in the early hours of the morning by dark-skinned "hantu Marege" (Aboriginal ghosts). Although the ghosts were not threatening, the experience was unsettling and not easily forgotten. It might be useful to establish whether the new house on the outskirts of Makassar, which will purportedly utilise the remaining Arnhem Land ironwood, is haunted as well. Given that intangible heritage such as ghosts and other paranormal activity are often associated with objects of tangible heritage, particularly in relation to objects of historical or spiritual significance to Aborigines, it would be not be surprising if there were reports of the new house being haunted.

\section{Museums, tombs and graveyards}

Makassar's other Macassan heritage sites can be summarised in a few paragraphs. The Makassar City Museum occasionally mounts a display on the Macassan trepang industry, such as that referred to by Macknight (2008, p. 141). At present, the City Museum holds mounted photographs relating to the Macassan voyages to Arnhem Land, as well as of joint theatre productions between Australian and Makassar-based performing arts groups. One of the mounted images is an intriguing map of the indigenous state of Gowa, which was a dominant local power around the city of Makassar by the end of the sixteenth century. According to this map, which has been observed in other locations in present-day Makassar (Cooke 1987, p. 45), Gowa's authority is shown to have stretched throughout eastern Indonesia and to the Northern Territory in the first half of the seventeenth century. According to Macknight (2008, p. 141), who has seen two editions of the map, 'the Top End of the Northern Territory is included with a date of \pm 1640 in the first edition of the work in 1967, and \pm is removed in the second edition of 1983'. Although most scholars would 
suggest that a map such as this one is unreliable (see Macknight 2008, p. 141), it is generally understood that Gowa's influence was felt on the east coast of Kalimantan, in Lombok and eastwards to the Aru-Kei island group (Ricklefs et al. 2010, pp. 160-1). Gowa's role as the main spice-trading state of eastern Indonesia attracted Asian and European communities, including the Dutch East India Company, whose attentions resulted in hostilities with Gowa in 1615. In the wake of this warfare, the peace treaty of Bungaya eventually brought Gowa's dominance of trade to an end. This information is not documented in the Makassar City Museum and the mounted photographs referred to above are currently locked in a dusty cabinet in one of the museum's ground-floor galleries.

Similarly difficult to locate is the tombstone of Puddu Daeng Tompo, who died about 1912. The tombstone is in a laneway off Jalan Somba Opu, behind Mesjid Ansar, the main mosque of Kampung Maloku, central Makassar (see Figure 10.3). Daeng Tompo was the main financier or entrepreneur (punggawa) of the Macassan trepang industry in its final stages. According to Macknight (1976, Plate 16), he probably devoted some of his profits to building the mosque, which might explain why his tombstone has remained reasonably well maintained to this day. Several prominent figures in the neighbourhood, including the Kampung Maloku district head and direct descendants of Daeng Tompo, informed us that Daeng Tompo owned much of the property in the area around the mosque, at the southern end of what is now Makassar's modest Chinatown.

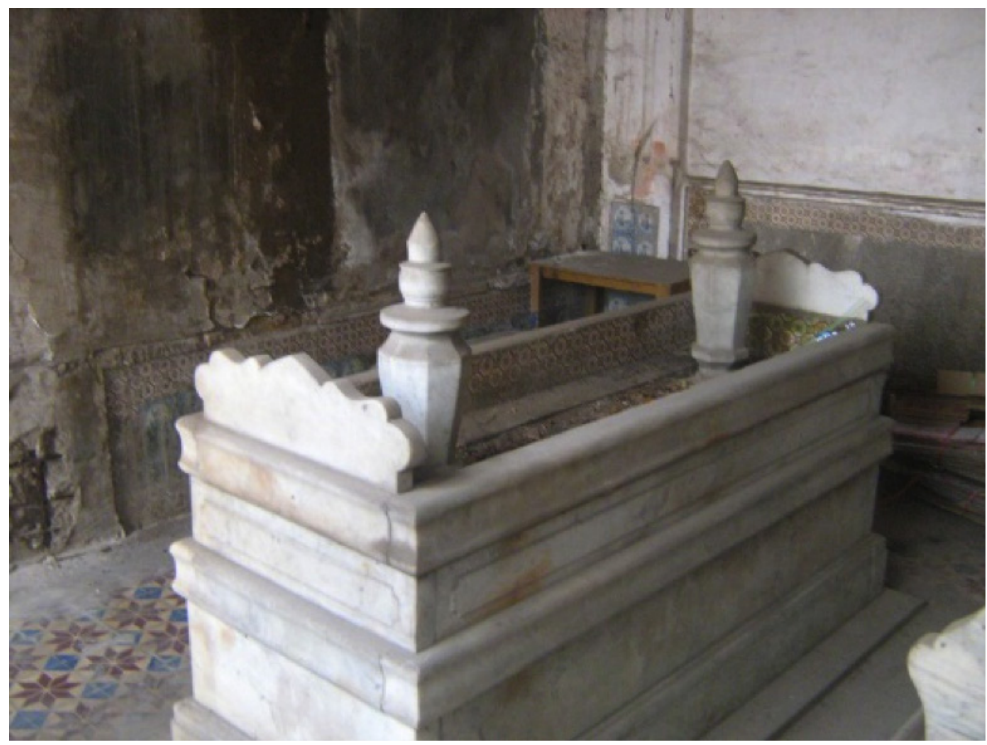

Figure 10.3 The tombstone of Puddu Daeng Tompo in Kampung Maloku, Makassar 
The final location of Macassan heritage that is worth highlighting is quite possibly in fact a series of sites. On the larger islands in the Spermonde Archipelago out from the Makassar coastline are a number of cemeteries said to contain the graves of fishers who voyaged to Arnhem Land. It is extremely difficult to ascertain simply by looking at the graves which are those of trepangers from the time of the Macassan trepang industry, and local people are unable to identify them either. The oldest graves are very dilapidated and many of them are unmarked, but it is very likely some of those buried beneath them were islanders involved in trepang fishing. According to Meereboer (1998, p. 257), 'some sea cucumber species were named after one of the islands, that is Kodingaring (Lompo), the southern-most island in this archipelago'. In 1823, at the height of the Macassan trepang industry, the kodingaring trepang, named after the Spermonde island, Kodingareng Lompo, were the most valuable and the pasir kodingaring, also named after Kodingareng, were the most expensive of them all (Sutherland 2000, p. 88). As noted earlier, it was a trepanger from one of the Spermonde islands who was said to have kidnapped an Aboriginal woman. There is a strong possibility, therefore, that the Spermonde cemeteries contain the graves of trepangers from the Macassan era, thus making them potentially sites of Macassan historical significance.

One of the largest of the Spermonde cemeteries can be found on Kodingareng Lompo, which is most probably the island Laklak Burarrrwanga referred to in her account of her trip to Sulawesi:

Then the next day we crossed in a Makassan boat to an island called Gunyaygarri, a small island about 1000 people staying there and it was also very difficult. There was an outside shower with the water hole. We saw the grave for the people who had been there, to Arnhem Land. It held people from Sulawesi who had been to Arnhem Land. They take them to that island to get away from the city when they got old and they died there. All the poles and flags were there. It's similar to here. One man took us to the wishing stone where they used to wish for the NE wind. It's a rock there (Burarrwanga 2012).

The island of Kodingareng Lompo, popularly known as Kodingareng, is indeed heavily populated and life there could well be described as 'very difficult' because of such inconveniences as outdoor showers located near wells. The 'wishing stone' mentioned in Laklak's account is not immediately identifiable in Kodingareng, but there are a number of very large boulders near the cemetery. There are also a number of Chinese tombstones that might be of marginal relevance. The calligraphy on the headstones of these imposing tombstones identifies them as marking the graves of Chinese entrepreneurs (see Figure 10.4). From my conversations with local residents, I learned that many of the Chinese who lived and died in the Spermonde islands were traders and trepang 
collectors. On Barrang Lompo, in particular, there are several very prominent Chinese tombstones, as well as the tombs of prominent Muslim traders or aristocrats, one of which is at the base of a $15 \mathrm{~m}$ high banyan tree - the roots of the tree literally grow in and around the tombstone, which is now part of the tree itself. Of course, none of this tangible Macassan history and heritage is documented or advertised and only mosque officials and the very oldest people in the community are able to give any account of the significance of these sites. In present-day Makassar and its environs there is little tangible evidence of a distinct Macassan cultural heritage. So, if there were to be such a thing as a Macassan heritage, what form would we like it to take? More precisely, in order to fulfil UNESCO's criteria for World Heritage listing, what shape or form might an appropriately managed Macassan heritage site or interpretative facility take? We can look to Malaysia for some answers.

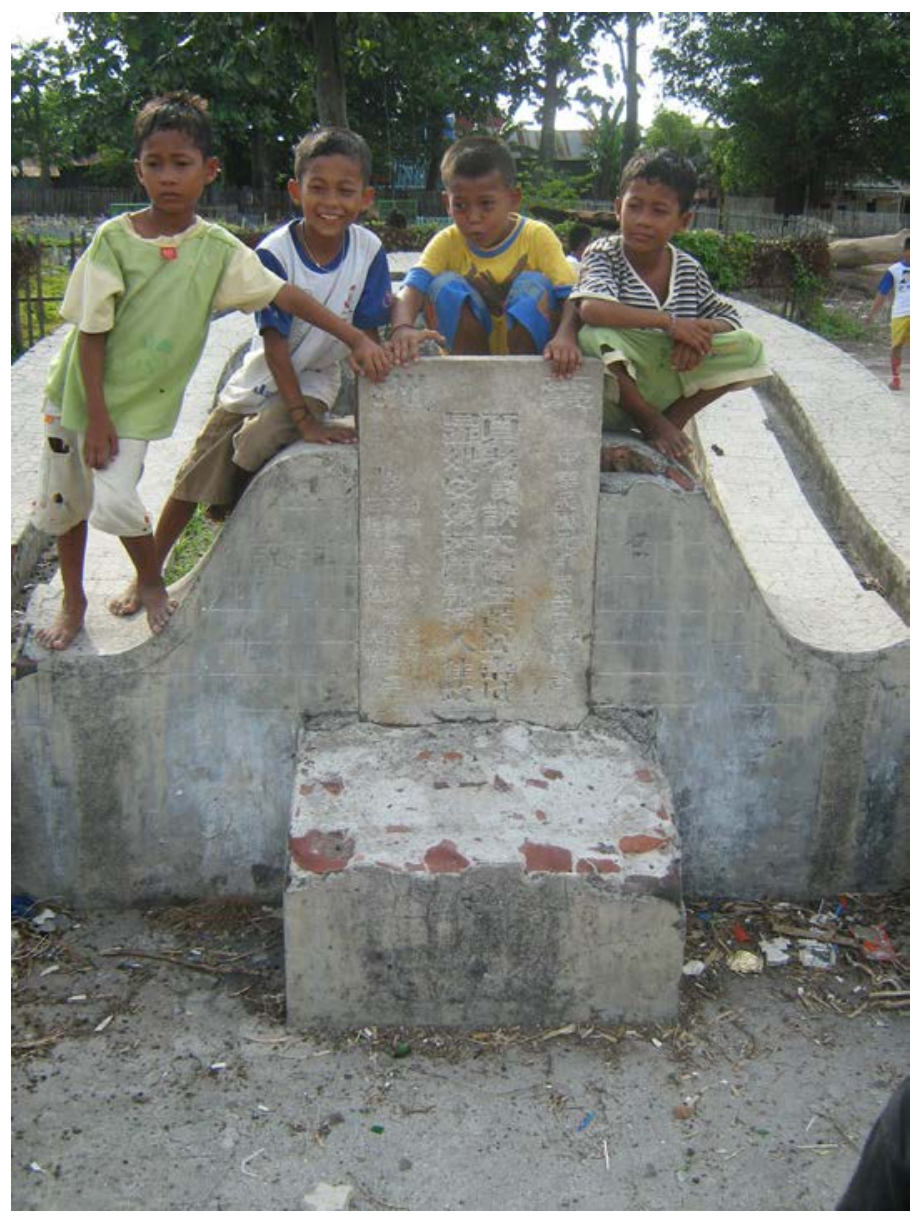

Figure 10.4 Chinese tombstone, Kodingareng Lompo Island

Source: Marshall Clark 


\section{Terengganu State Museum}

A good example of what could have been labelled a seemingly ideal Macassan interpretative facility is the Fisheries Gallery at Kuala Terengganu's Terengganu State Museum, Malaysia. In one sense, using a Malaysian example to support an argument for the identification of heritage sights in Indonesia is a little unfair as it is, after all, Malaysian, rather than Indonesian. Yet, as anyone who has stepped inside a museum in Indonesia, Malaysia or Singapore can attest, the archipelagic and peninsular Malay worlds share a great deal, especially in terms of history and heritage. Indeed, museums in each nation - above the protestations of Indonesian football fans and online commentators - magnanimously showcase many of the same cultural traditions, such as batik, wayang, gamelan and keris. The origins of many of these heritage items, be they the Bugis of southwestern Sulawesi, the Minangkabau of western Sumatra or the Javanese of central and eastern Java, are also publicly acknowledged. This theme of cultural affinity is a common thread uniting the Indonesian/Malay archipelago. Moreover, Kuala Terengganu, like Makassar, is a port city with a long and proud history as a coastal hub, connecting the trading vessels of the eastern Malay Peninsula with the Bugis traders of Sulawesi and vessels from China, Thailand, Vietnam and elsewhere in the Malay world. So, in an important sense, Makassar and Kuala Terengganu have more similarities than differences.

In terms of physical structure, the Terengganu State Museum is the largest museum in Malaysia. Several displays in the museum highlight the close historical links between Terengganu and Sulawesi, in the fashion gallery, where the batik styles of Terengganu are placed alongside the silk batik styles of the ethnic Bugis. To this day, the Bugis 'boxed', or quadrate, silk batik motif is very popular in Terengganu, if not all of Malaysia, and can be seen in many items, including sarongs, blinds, tablecloths and seat furnishings.

Outside the Terengganu Museum building, two schooners are housed in the museum grounds: a Perahu Besar (big boat) and a Pinis Dogol (Dogol schooner). The semantic link between the Malay pinis and the Bugis pinisi is evident in the two words and supports claims that for many centuries there were strong trade links between the coastal kingdoms of peninsular Malaysia and the seafaring Bugis, who were distinguished by the majestic pinisi schooners they sailed (Ricklefs et al. 2010). The value of each of the pinisi vessels at the Terengganu Museum is such that security guards are camped nearby and the boats appear to be closed for onboard tours while renovations occur. Although there may be conservation and preservation concerns with the present set-up, the location of both boats - barely $20 \mathrm{~m}$ from the banks of the Terengganu River, which is often swollen by heavy rains, especially during the monsoon season-is in one 
sense perfect. Each boat has appropriate interpretative signs, in English, Malay and Chinese, giving full and helpful details of its style, provenance and sailing history, and of historical links with the Bugis pinisi.

The Bugis, like the Indians and Chinese, have had an important and widely influential role in the history of the Malay Peninsula. After the rise of a Bugis dynasty in Aceh in 1727, Bugis power was established in the Kingdom of Johor in 1728. According to various accounts, a branch of the Bugis royal family was transferred to the Johor line after a particularly brutal regicide. The Bugis domiciled in Riau and Johor took pains to demonstrate their support of the Malays and their traditional institutions (Andaya 2010, p. 139). Intermarriage with Malay royalty and nobility enabled the Bugis to identity with and become increasingly 'Malay', and their influence spread throughout the peninsula. In 1766, for instance, Raja Lumu, son of the powerful Bugis Raja Muda of Johor, was installed as the first Sultan of Selangor (Andaya 2010, pp. 228-9). Although the Bugis are relatively recent settlers and, therefore, associated with a home area outside Malaysia (Andaya 2010, p. 13), in the post-colonial era the links between the Bugis and the Malays have proven to be a cause of great pride for both peoples. For example, Makassar has a street named Jalan Tun Abdul Razak, which recognises the much-publicised fact that both Malaysia's first prime minister and the prime minister at the time of writing this chapter can trace their lineage back directly to the sixteenth-century Bugis royal line of the Bugis-Makassarese Kingdom of Gowa. The present-day royal family of Johor is equally proud to share these ties with Bugis royalty. Occasionally Malaysian Government delegations tour Makassar, where they are met with great fanfare. ${ }^{4}$

Returning to our discussion of the Terengganu State Museum, not far from the large pinisi schooners is another area where several full-sized fishing and trading prau are displayed. These vessels are included in the museum because they are used in the Terengganu area, both up its rivers and in the open seas. Each replica has an accompanying interpretative sign in English and Malay, discretely located to respect the great care taken both in the preservation of the boats and in the landscape of the site. Indeed, in the prau exhibition precinct one is likely to encounter half-a-dozen gardeners, such is the care being taken to maintain a site that is beautified with ornamental flowers and trees and with water features around each display island, on which the boats are raised above the ground. Visitors can take any number of routes through the display islands to the Fisheries Gallery, which in many ways is exactly what Makassar needs to display its fishing heritage.

Inside the Fisheries Gallery, Terengganu's maritime history is revealed, with an emphasis on local history, through the use of dioramas. Displays focus on such

4 My thanks to Raimy Ché-Ross for this observation. 
things as the types of vessels used in the Terengganu region, traditional nets and fish traps together with modern trawler nets, hooks, sinkers and fishing lines of all shapes and sizes, the clothing of traditional Malay fishers, and decorated prau prows, some of which represent characters from the traditional wayang kulit shadow theatre. About $90 \mathrm{~m}$ from this gallery, along the riverbank, a small footbridge passes halfway across the Terengganu River to a small island, Pulau Sekati. Inhabitants of this island, ethnic Malays, collect coconuts from the island's many coconut trees to sell to the museum's cafeteria. Although Pulau Sekati is not officially part of the museum, the detour certainly enhances the maritime ambience of the seafaring and fishing section of the museum.

What if there were to be a similar museum, in similar marine environs, in Makassar? After all, Makassar's maritime heritage is no less impressive than that of Terengganu. ${ }^{5}$ But, it is unrealistic to assume that the experience of setting up a museum in Malaysia has any relevance to preserving maritime heritage in Indonesia. Compare, for instance, the Terengganu museum's army of security guards and gardeners with the army of highly skilled boatbuilders and trepang fishers one encounters anywhere along the southern Sulawesi coastline. It is no secret that foreign workers, including many Indonesian fishing crews, are the mainstay of Malaysia's fishing industry, not to mention its very limited boatbuilding industry. In a more general sense, it could be argued that the comparison neatly highlights the difference between middle-class Malaysia's thoroughly museumised cultural heritage and developing Indonesia's living history continuum. In Indonesia, especially in South Sulawesi, trepang fisheries and trade and traditional prau building are still big business.

\section{South Sulawesi's living maritime heritage}

If we expand our understanding of Macassan history and heritage to include post-Macassan trepang fisheries and trade, it soon becomes evident that Makassar's Macassan heritage is alive and well. It is convincingly demonstrated in a number of locations and contexts: Makassar's proud maritime culture; Makassar's Paotere Harbour, where many traditional prau wooden sailing vessels come and go; the traditional wooden boatbuilding industry of Bulukumba in southern Sulawesi; and the contemporary trepang fishery, in which Bugis and Makassarese trepangers from the Spermonde islands and from Makassar participate.

5 In Makassar, the maritime display in the La Galigo Museum in Fort Rotterdam is the closest one can get to Terengganu's impressive maritime and fisheries display. It must be said that it is not in any sense a very good display, in which the boats are miniature models rather than life-size replicas. 
Makassar's much-vaunted maritime culture, based on centuries of demonstrated seafaring prowess by the Bugis and the Makassarese, is acknowledged still in many ways, most obviously in the many statues and images displaying traditional Bugis pinisi. The masthead of the Makassar edition of the Tempo newspaper is distinguished by an image of a pinisi, and the architectural facade on the top storey of the building housing the local newspaper, Fajar, replicates the style of a billowing pinisi sail. Makassar's inexpensive seafood cuisine is well known throughout the region and one of Indonesian President Susilo Bambang Yudhoyono's favourite restaurants is said to be a seafood grill not far from Makassar's Paotere boat harbour. At Paotere, echoes of the Macassan trepang industry can be seen every day, as trepang specimens are sometimes sold at the open-air fish market. Many wooden sailing vessels line the harbour (see Figure 10.5). They are still known as praus (perahu), as they were in the Macassan industry era (Macknight 1976). The praus moored at Paotere are intraregional fishing boats, inter-island goods transportation boats and local ferries, many of which connect the populations of the nearby Spermonde islands with the major businesses and educational institutions of the region in Makassar. Indeed, schoolchildren travel from the many Spermonde islands each morning to attend school in Makassar. Apart from motors, these praus have very little in the way of modern fishery and maritime technological accoutrements, such as sonar, radar, GPS and satellite beacons. As in the Macassan era, many of the contemporary fishers and traders making their way to and from Makassar rely on traditional navigation methods, such as the position of the stars and a deep and intimate knowledge of all the islands, ports, reefs, straits and other major landmarks passed down through generations.

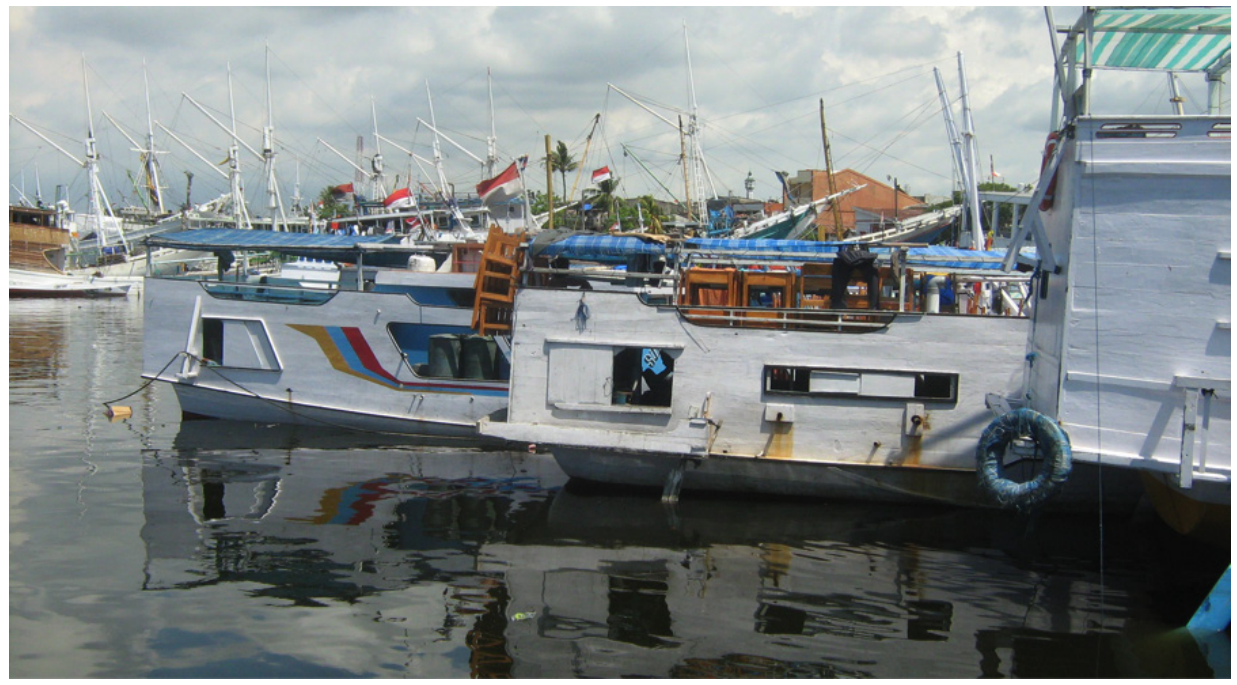

Figure 10.5 Moored prau at the Paotere boat harbour, Makassar

Source: Marshall Clark 
As noted above, most of the many sailing vessels frequenting Makassar's harbours and ports are prau, made almost entirely of wood. Although some boats are built in the offshore islands of the Spermonde Archipelago, the region of Bulukumba, on the southernmost shores of South Sulawesi's peninsula about three-and-a-half hours southeast of Makassar, remains Indonesia's best-known hub for wooden boatbuilding. Here, the sandy shores are lined with stalls devoted to the construction of prau of all shapes and sizes (see Figure 10.6). After I had spoken to many boatbuilders along the shores of Bulukumba's heritage town of Tanah Beru in particular, it became evident to me that many of the completed prau, particularly perahu padewakang (trading prau), end up in the Spermonde islands, where fishers continue to fish for trepang (see Figure 10.7). In many ways, these present-day trepangers, mostly of Bugis or Makassarese ethnicity (or a combination of both), are the contemporary embodiments of the Macassans of centuries past. Although the supply of trepang in the Makassar area, and indeed throughout the Indonesian archipelago, is greatly diminished (Choo 2008), large quantities continue to be collected and processed in Makassar and its environs for export to China, Singapore, South Korea and Malaysia. The consistently high prices that the trepangers get for their trepang are what drive the industry, which, according to members of the fishing community of South Sulawesi, is still centred in Makassar, with the Javanese port of Surabaya also playing a significant role.

It should be emphasised that most of the present-day Bugis-Makassarese trepangers are based offshore in the Spermonde islands, where the trepang (see Figure 10.8) are initially processed and cured by 'pengumpul teripang lokal' (local trepang collectors) (see Figure 10.9). As is the case elsewhere in the Indonesian archipelago (see Adhuri, this volume), Spermonde trepangers focus on more profitable species, such as tripang susu or koro susu (white teatfish, Holothuria fuscogilva) and tripang nanas (prickly redfish, Thelenota ananas). Many other species, however, are caught and processed for sale, including cerak hitam (lollyfish, Holothuria atra), teripang ballang ulu (surf redfish, Actinopyga mauritiana), and tripang hitam (black teatfish, Holothuria whitmaei). After initial processing on the praus, or on jetties or dry land in the Spermonde islands, the trepang are then delivered to Makassar-based trepang collectors, known as 'pengumpul teripang'. These pengumpul teripang procure and then process the trepang to meet the particular requests and demands of the overseas markets. Thus, as in the heyday of the Macassan trepang industry in the mid 1800s (Meereboer 1998; Sutherland 2000), today Makassar remains a vital hub for the fishing, processing and exporting of trepang. Makassar-based middlemen continue to play just as an important role in the industry as the trepang fishers do. Makassar is, however, not the only centre of the trepang trade, and diasporic communities of Bugis-Makassarese trepang fishers are to be found throughout the Indonesian archipelago. Many of these trepangers, by the way, report that they have fished Australian waters on numerous occasions, despite the harsh punishments. 


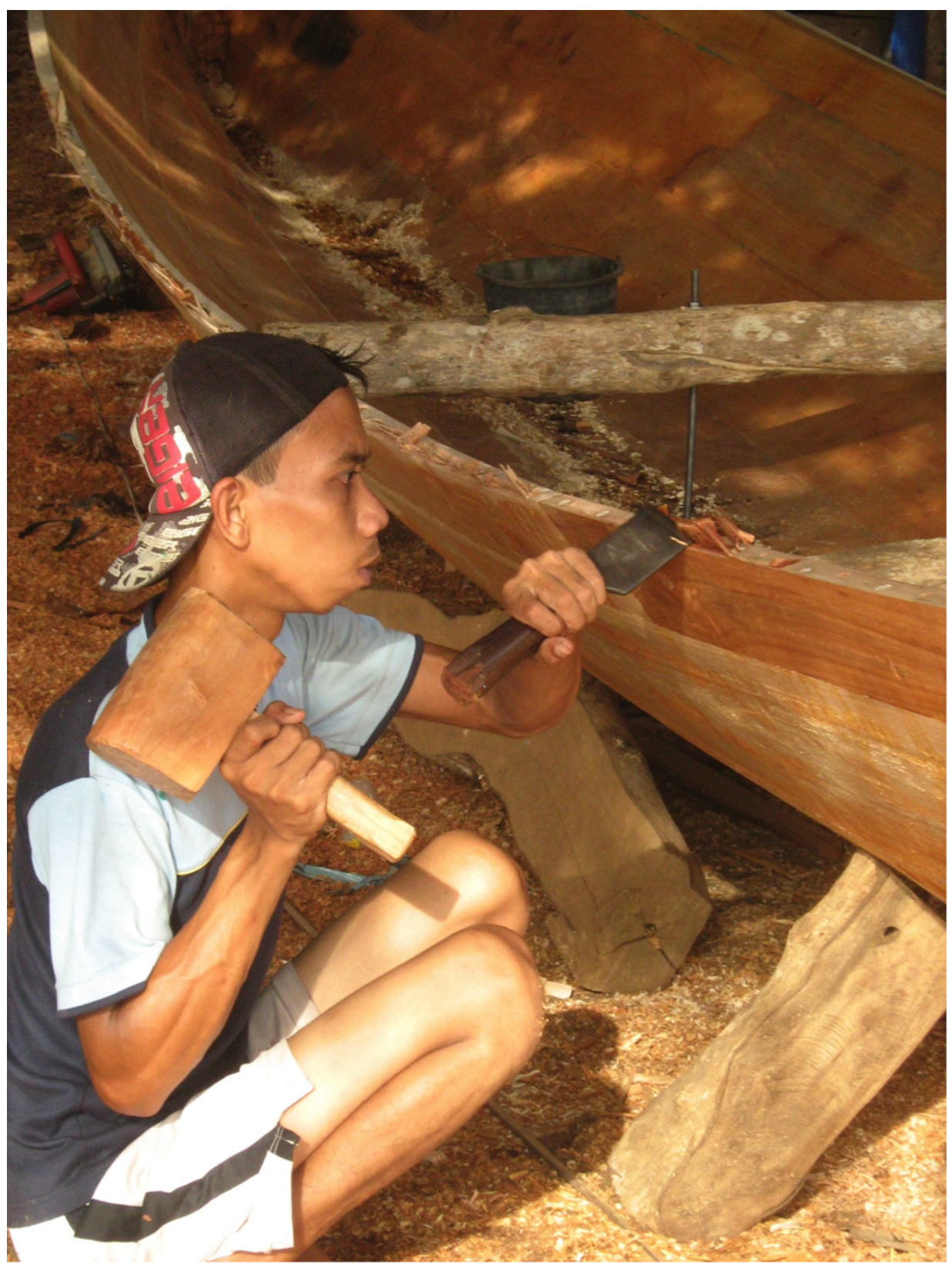

Figure 10.6 Boatbuilding at Tanah Beru, South Sulawesi

Source: Marshall Clark 


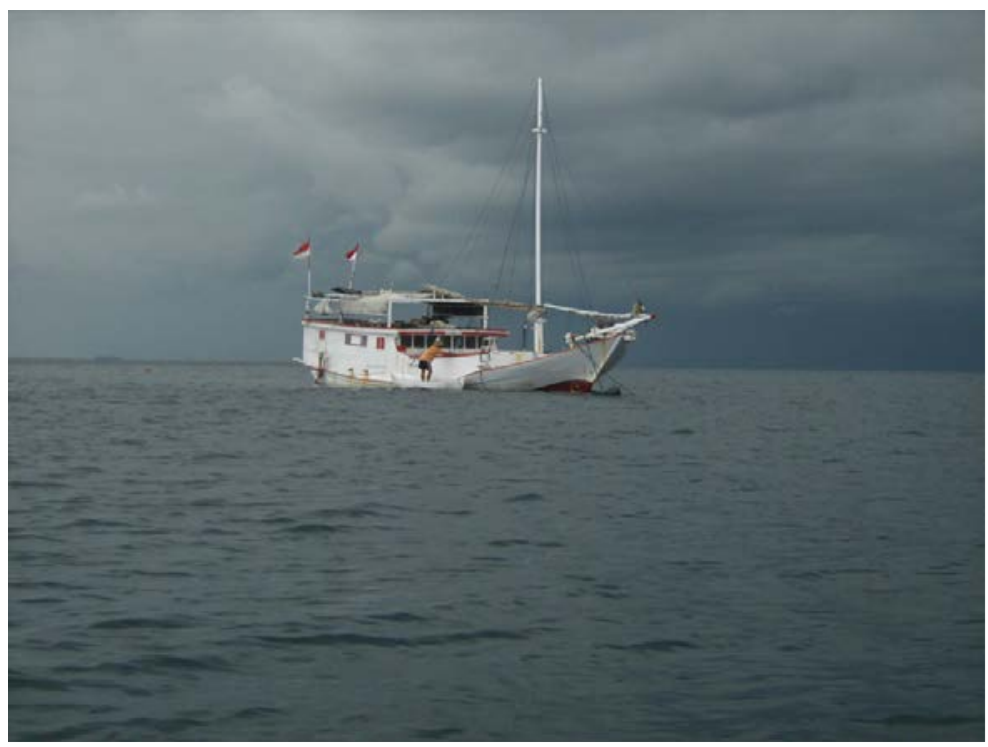

Figure 10.7 Perahu padewakang, used for trepang fishing, in the Spermonde Archipelago, South Sulawesi

Source: Marshall Clark

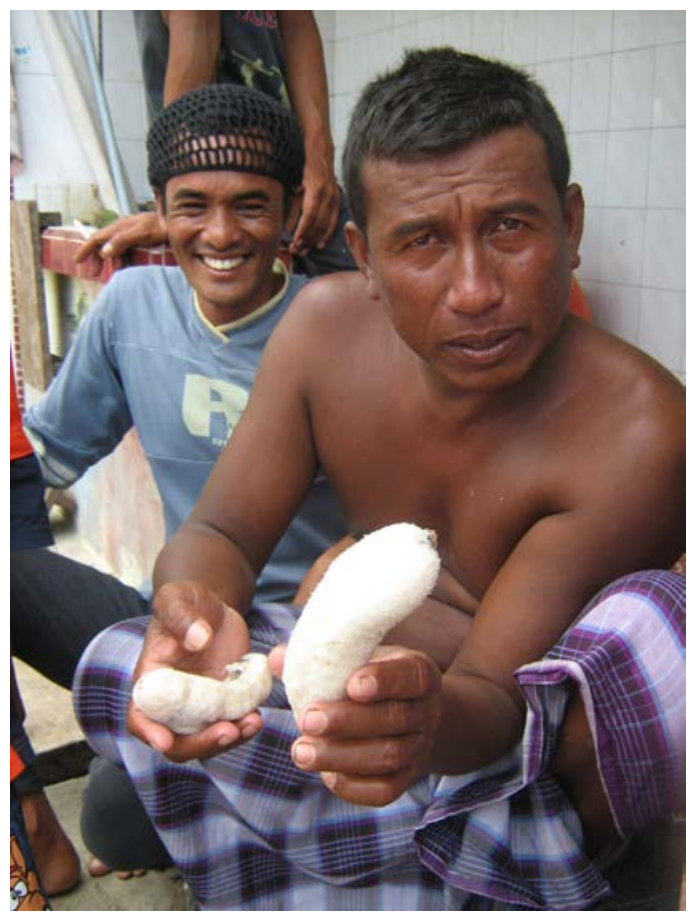

Figure 10.8 A trepanger with cured tripang susu (white teatfish), Barrang Lompo Island, Spermonde Archipelago 


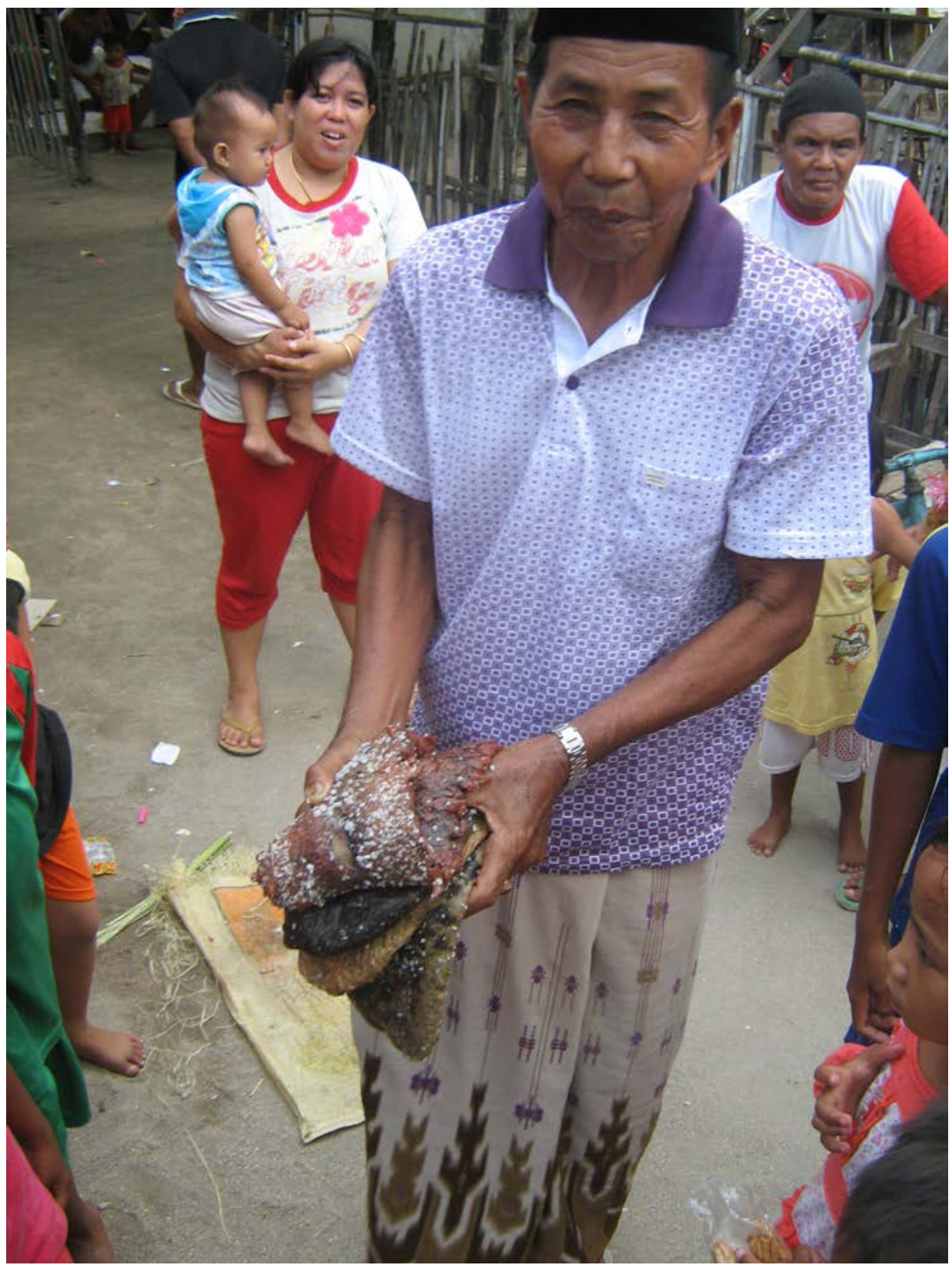

Figure 10.9 A 'pengumpul teripang lokal' (local trepang collector), with uncured trepang including tripang nanas (prickly redfish) (top), tripang ballang ulu (surf redfish) (middle) and tripang susu (white teatfish) (bottom), Kodingareng Lompo Island, Spermonde Archipelago 


\section{Conclusion}

This chapter has drawn attention to examples of what could be regarded as Makassar's sites that can be viewed as displaying important aspects of a Macassan tangible cultural heritage. Almost all of them provide fresh insights into the little-known local impact of the centuries of interaction between the trepangers of the Indonesian archipelago and Aboriginal communities of northern Australia; however, at none of the sites can satisfactory levels of general protection and management be demonstrated. One site in particular - the twostorey house said to have been made of ironwood from Arnhem Land in Jalan Maipa - has very recently been demolished to make way for the expansion of a luxury hotel. None of the sites has proper visitor reception and interpretative facilities, unless one takes into account the ubiquitous groups of interested neighbours and onlookers who are able to recount or embellish well-known oral history narratives.

Through an examination of the maritime and fisheries displays of the Terengganu State Museum in the Malaysian port city of Kuala Terengganu, this chapter has outlined what might be achieved in Makassar should a concerted effort be made to create a museumified or static form of cultural expression to showcase Makassar's rich maritime heritage; however, a negative comparison with a Malaysian institution does little to help explain Makassar's deeply layered Macassan history and heritage. Unlike economically advanced Malaysia, Indonesia might not yet be ready for its rich and continuous cultural heritage to be mothballed and museumised, for the simple reason that much of Indonesia's traditional heritage, such as fishing praus, is still in use. This is particularly the case in South Sulawesi, whose coastal communities are among Indonesia's poorest, where many fishing folk eke out a meagre existence on small fishing boats in primarily artisanal fisheries. In present-day Sulawesi, Makassar's maritime history is very much an ongoing cultural process that is still being lived on a daily basis.

If we move beyond the previously hegemonic Western understanding of cultural heritage conservation, in which 'cultural heritage resided mainly in great monuments and sites' (Taylor 2009, p. 14), it becomes evident that South Sulawesi's Macassan history is far from non-existent, especially if we consider Makassar's contemporary maritime culture and trepang fisheries. If we regard the contemporary trepang fishers, trepang collectors and wooden boatbuilders of southern Sulawesi as participants in Makassar's living history continuum then we can argue that Makassar's Macassan past has clearly not yet ended, just as the Makassar-based trepang fishers did not entirely cease their trepang collecting along the northern coast of Australia after the 1906-7 season. There is no doubt that trepang fishing continues in earnest in South Sulawesi and 
its environs, despite decreasing catch sizes. Many islands in the Spermonde Archipelago, offshore from Makassar, remain economically dependent on the international trepang trade. On these same islands there are numerous middleaged trepangers - some of whom are captains or financiers of the current generation of trepang vessels - who are proud of the fact that they fished in Australian waters in the 1980s and 1990s, despite this illegal fishing resulting in detention and the destruction of their praus.

It is easy to question Indonesia's commitment to preserving its culture, heritage and traditions, as history has little honour. This chapter, however, has suggested that much of Indonesia's intangible cultural heritage is still in use, which adds layers of complexity to our understanding of Indonesia's heritage, especially when we compare it with the heritage of Malaysia and its preservation and management.

\section{References}

Adams, K. M. (2003) 'Museum/city/nation: negotiating identities in urban museums in Indonesia and Singapore', in R. Goh and B. Yeoh (eds), Theorizing the Southeast Asian City as Text: Urban landscapes, cultural documents and interpretive experiences, Singapore: World Scientific Publishing.

Adams, K. M. (2006) Art as Politics: Re-crafting identities, tourism, and power in Tana Toraja, Indonesia, Honolulu: University of Hawai'i Press.

Adams, K. M. (2010) 'The politics of heritage in Tana Toraja, Indonesia: interplaying the local and the global', Indonesia and the Malay World, 31 (89), pp. 91-107.

Andaya, L. Y. (2010) Leaves of the Same Tree: Trade and ethnicity in the Straits of Melaka, Singapore: NUS Press.

Behr, E. (1990) Indonesia: A voyage through the archipelago, Paris: Millet Weldon Owen Ltd.

Bharucha, R. (2000) 'Beyond the box: problematising the new Asia museum', Third Text, 52, pp. 11-19.

Burarrwanga, L. L. (2012) Memories of my Makassan family, Paper presented to Macassan History and Heritage: Building Understandings of Journeys, Encounters and Influences, 8-9 February, The Australian National University, Canberra. 
Choo, P. (2008) 'Population status, fisheries and trade of sea cucumbers in Asia', in V. Toral-Granda, A. Lovotelli and M. Vasconcellos (eds), Sea Cucumbers: A global review of fisheries and trade, Rome: Food and Agriculture Organization of the United Nations.

Cooke, M. (1987) Makassar and Northeast Arnhem Land: Missing links and living bridges, Batchelor, NT: Educational Media Unit, Batchelor College.

Derks, W. (1996) "If not to anything else": some reflections on modern Indonesian literature', Bijdragen tot de Taal-, Land-en Volkenkunde, 152 (3), pp. 341-52.

Derks, W. (2002) 'Sastra pedalaman: local and regional literary centres in Indonesia', in K. Foulcher and T. Day (eds), Clearing a Space: Postcolonial readings of modern Indonesian literature, Leiden: KITLV Press.

Ganter, R. (2006) Mixed Relations: Asian/Aboriginal contact in north Australia, Perth: University of Western Australia Press.

Greenough, P. (1993) 'Nation, economy and tradition displayed: the Indian Crafts Museum, New Delhi', in C. A. Breckenridge (ed.), Consuming Modernity: Public culture in a South Asian world, Minneapolis: University of Minnesota Press.

Henderson, J. (2005) 'Exhibiting cultures: Singapore's Asian Civilisations Museum', International Journal of Heritage Studies, 11 (3), pp. 183-95.

Hoffstaedter, G. (2008) 'Representing culture in Malaysian cultural theme parks: tensions and contradictions', Anthropological Forum, 18 (2), pp. 139-60.

Knaap, G. (2001) 'Manning the fleet: skippers, crews and shipowners in eighteenth-century Makassar', in E. Sedyawati and S. Zuhdi (eds), Arung Samudra: Persembahan Memperingati Sembilan Windu A. B. Lapian, Depok: Pusat Penilitian Kemasyarakatan dan Budaya \& Lembaga Penelitian Universitas Indonesia.

Lloyd, K., S. Suchet-Pearson, S. Wright and L. Burarrwanga (2010) 'Stories of crossings and connections from Bawaka, north east Arnhem Land, Australia', Social \& Cultural Geography, 11 (7), pp. 701-17.

Macknight, C. C. (1976) The Voyage to Marege': Macassan Trepangers in northern Australia, Carlton, Vic.: Melbourne University Press.

Macknight, C. C. (2008) 'Harvesting the memory: open beaches in Makassar and Arnhem Land', in P. Veth, P. Sutton and M. Neale (eds), Strangers on the Shore: Early coastal contacts in Australia, Canberra: National Museum of Australia. 
Macknight, C. C. (2011) 'The view from Marege': Australian knowledge of Makassar and the impact of the trepang industry across two centuries', Aboriginal History, 35, pp. 121-43.

Malaysian National Commission for UNESCO (2008) Malaysia: 50 years of membership in UNESCO, Kuala Lumpur: NATCOM.

Meereboer, M. (1998) 'Fishing for credit: patronage and debt relations in the Spermonde Archipelago, Indonesia', in K. Robinson and M. Paeni (eds), Living through Histories: Culture, history and social life in South Sulawesi, Canberra: Department of Anthropology, Research School of Pacific and Asian Studies, The Australian National University.

Nor, M. A. M. (2011) 'Eclecticism and syncretic traditions: the making of Malay folk dance', in M. A. M. Nor and S. Buddidge (eds), Sharing Identities: Celebrating dance in Malaysia, London: Routledge.

Pemberton, J. (1994) On the Subject of 'Java', Ithaca, NY, \& London: Cornell University Press.

Peycam, P. (2012) 'Broadening intercultural dialogue', The Newsletter, 62, p. 3.

Raslan, K. (1996) Ceritalah: Malaysia in transition, Singapore: Times Books International.

Ricklefs, M. C., B. Lockhart, A. Lau, P. Reyes and M. Aung-Thwin (2010) A New History of Southeast Asia, Basingstoke, UK: Palgrave Macmillan.

Stephenson, P. (2007) The Outsiders Within: Telling Australia's Indigenous-Asian story, Sydney: UNSW Press.

Sutherland, H. (2000) 'Trepang and wangkang: the China trade of eighteenthcentury Makassar c. 1720s-1840s', in R. Tol, K. van Dijk and G. Acciaioli (eds), Authority and Enterprise among the Peoples of South Sulawesi, Leiden: KITLV Press.

Taylor, K. (2009) 'Cultural landscapes and Asia: reconciling international and Southeast Asian regional values', Landscape Research, 34 (1), pp. 7-31.

Waterson, R. (2011) Paths and Rivers: Sa'dan Toraja society in transformation, Leiden: KITLV Press. 